\title{
THE ABNORMALITY OF TRYPTOPHANE METABOLISM IN CHILDREN WITH MONGOLISM
}

\author{
BY \\ DONOUGH O'BRIEN and ANN GROSHEK \\ From the Department of Pediatrics, University of Colorado Medical Center, Denver, \\ and the Colorado State Home and Training School, Wheatridge, Colorado
}

(RECEIVED FOR PUBLICATION JULY 4, 1961)

There is evidence (Gershoff, Hegsted and Trulson, 1958; Jérôme, Lejeune and Turpin, 1960; O’Brien, Groshek and Streamer, 1960) that children with mongolism have a defect in tryptophane metabolism which is characterized primarily by a diminished urinary excretion of xanthurenic acid.

The purpose of this study was to confirm this observation using more exact techniques and to attempt to specify the alteration in metabolism more precisely by comparing the effects of 1-tryptophane loading on the urinary excretion coefficients ( $\mu$ mols/ kg./7 hours) of both 5-hydroxy-3-indoleacetic acid and the kynurenine pathway metabolites of tryptophane in a group of children with mongolism and in a control group of non-mongoloid mentally retarded children.

\section{Methods}

Twenty-one children with mongolism, aged 9 to 16 years, and 19 non-mongoloid mental defectives of comparable age, sex and intelligence were studied. All the children were active, able to feed themselves and keep themselves clean. Both groups were in the same institution and received an identical diet. At the commencement of the test, fasting subjects voided and then drank $300 \mathrm{ml}$. of flavoured milk in which was suspended $100 \mathrm{ml} . / \mathrm{kg}$. body weight of 1-tryptophane. All urine was collected for seven hours after the tryptophane load, and, to ensure completeness, individual voidings were supervised by one or other of the investigators. This seven-hour collection period was chosen as being the longest period that could be properly monitored.

A measured aliquot of urine was assayed for 5-hydroxy3-indoleacetic acid (Udenfriend, Titus and Weissbach, 1955), $\mathrm{N}^{1}$-methylnicotinamide (Huff and Perlzweig, 1947; Asami, 1957), and 4-pyridoxic acid (Reddy, Reynolds and Price, 1958). Other metabolites of the kynurenine pathway were separated by two-dimensional paper chromatography and identified under ultraviolet light. These were then eluted and estimated either directly by their absorbance in the ultraviolet, or as azo compounds coupled with pyridine or naphthylethylenediamine (Coppini, Benassi and Montorsi, 1959; O'Brien and Ibbott, 1962a). The chromatographic methods were linear within the experimental range and recoveries for kynurenine, acetylkynurenine, kynurenic acid, hydroxykynurenine, xanthurenic acid and hydroxyanthranilic acid gave a mean value of $97 \cdot 6 \%(82 \cdot 5-104 \cdot 7 \%)$ with a mean coefficient of variation of $7 \cdot 9 \%(4 \cdot 6-12 \cdot 6 \%)$. Reproducibility, expressed also as a coefficient of variation, averaged $4.7 \%$ for standards and $5.9 \%$ for urine samples. These figures were shown to be slightly, but not significantly, better than those for column chromatography techniques (Satoh and Price, 1958) in the cases of kynurenic and xanthurenic acids.

Because intravenous tryptophane loading was not permitted, fasting, one- and two-hour serum samples were obtained for estimation of the tryptophane levels. These were determined as the enol-borate complex after adsorption and elution from a Dowex 50 column (O'Brien and Ibbott, 1962b).

TABLE 1

URINARY EXCRETION COEFFICIENTS OF 4-PYRIDOXIC ACID ( $\mu \mathrm{g} . / \mathrm{kg} . / 7$ hour period)

\begin{tabular}{l|c|c|c}
\hline & $\begin{array}{c}\text { Mongols } \\
\text { (20 Obser- } \\
\text { vations) }\end{array}$ & $\begin{array}{c}\text { Non- } \\
\text { mongols } \\
\text { (18 Obser- } \\
\text { vations) }\end{array}$ & $\begin{array}{c}\text { Signi- } \\
\text { ficance* }\end{array}$ \\
\hline Mean & $\ldots .7$ & $\begin{array}{c}2.4 \\
1.7\end{array}$ & $\begin{array}{c}\mathrm{p}<0.10 \\
\mathrm{p}>0.05\end{array}$ \\
\hline
\end{tabular}

* Trickett, Welch and James (1956).

\section{Results}

The urinary excretion coefficients ( $\mu \mathrm{mols} / \mathrm{kg}$./ 7 hours) of 5-hydroxy-3-indoleacetic acid and of the metabolites of the kynurenine pathway are set out in Fig. 1. These show that, whereas the children with mongolism excreted uniformly less of all these metabolites than the non-mongols, the differences were highly significant only for xanthurenic acid and to a lesser degree for acetyl kynurenine. There was no difference (Table 1) between the two groups in the amount of 4-pyridoxic acid excreted in the urine. 


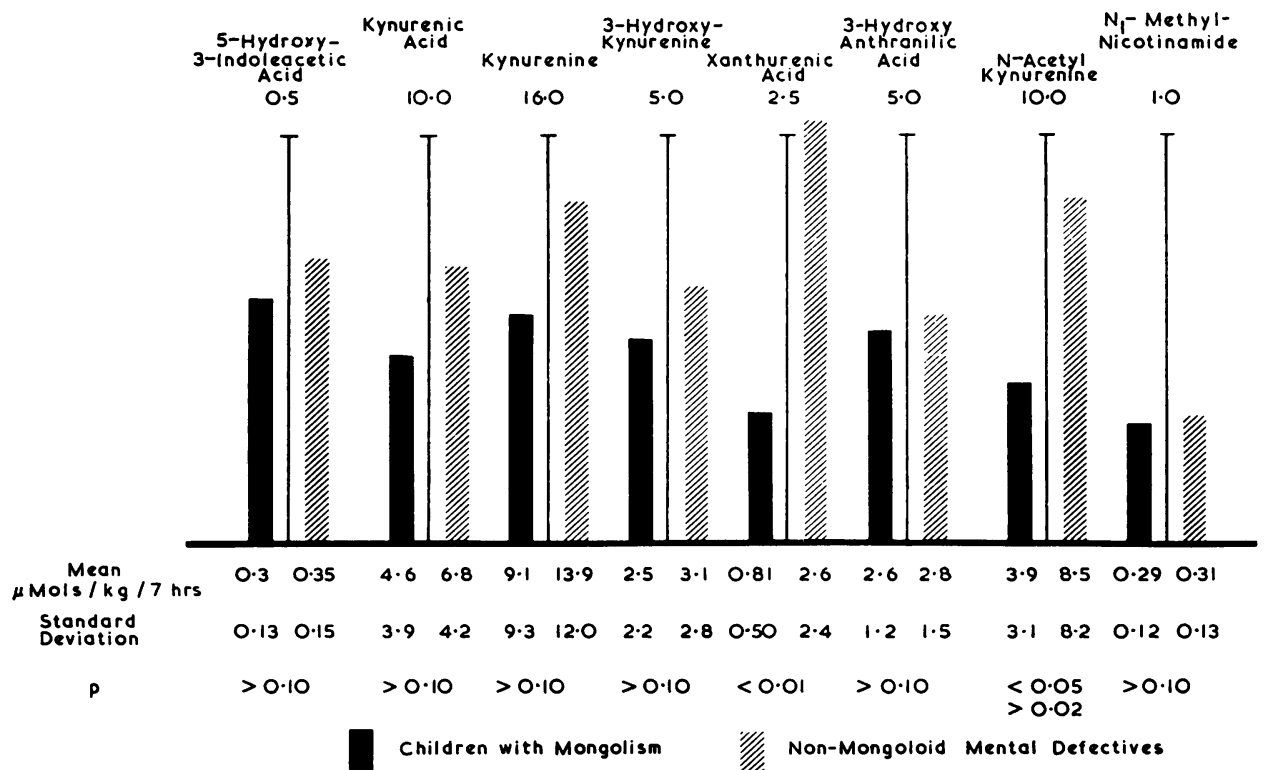

FIG. 1.-Urinary excretion coefficients of tryptophane metabolites following an oral loading dose of $100 \mathrm{mg}$. (490 $\mu \mathrm{mols}) / \mathrm{kg}$. body weight of 1-tryptophane ( $\mu \mathrm{mols} / \mathrm{kg}$. $/ 7$ hours).

TABLE 2

MEAN SERUM TRYPTOPHANE LEVELS IN mg. $/ 100 \mathrm{ml}$. AT ONE AND TWO HOURS, FOLLOWING AN ORAL LOADING DOSE OF $100 \mathrm{mg} . / \mathrm{kg}$. BODY WEIGHT OF 1-TRYPTOPHANE

\begin{tabular}{|c|c|c|c|}
\hline & $\begin{array}{l}\text { Mongols } \\
\text { (21 Obser- } \\
\text { vations) }\end{array}$ & $\begin{array}{c}\text { Non- } \\
\text { mongols } \\
\text { (19 Obser- } \\
\text { vations) }\end{array}$ & $\begin{array}{l}\text { Signi- } \\
\text { ficance }\end{array}$ \\
\hline $\begin{array}{l}\text { Pre-loading } \\
\text { Mean } \\
\text { Standard deviation }\end{array}$ & $\begin{array}{l}1 \cdot 8 \\
1 \cdot 3\end{array}$ & $\begin{array}{l}1 \cdot 8 \\
0 \cdot 75\end{array}$ & $p>0 \cdot 10$ \\
\hline $\begin{array}{l}\text { One hour } \\
\text { Mean } \\
\text { Standard deviation }\end{array}$ & $\begin{array}{l}7 \cdot 1 \\
2 \cdot 7\end{array}$ & $\begin{array}{l}8 \cdot 7 \\
2 \cdot 7\end{array}$ & $\begin{array}{l}p<0.10 \\
p>0.05\end{array}$ \\
\hline $\begin{array}{l}\text { Two hours } \\
\text { Mean } \\
\text { Standard deviation }\end{array}$ & $\begin{array}{l}8 \cdot 5 \\
2 \cdot 6\end{array}$ & $\begin{array}{l}9 \cdot 8 \\
2 \cdot 9\end{array}$ & $p>0.10$ \\
\hline
\end{tabular}

TABLE 3

THE RISE IN SERUM TRYPTOPHANE LEVELS IN $\mathrm{mg} . / 100 \mathrm{ml}$ FOLLOWING AN ORAL LOADING DOSE OF $100 \mathrm{mg} . / \mathrm{kg}$ BODY WEIGHT OF 1-TRYPTOPHANE

\begin{tabular}{|c|c|c|c|}
\hline & $\begin{array}{l}\text { Mongols } \\
\text { (21 Obser- } \\
\text { vations) }\end{array}$ & $\begin{array}{c}\text { Non- } \\
\text { mongols } \\
\text { (19 Obser- } \\
\text { vations) }\end{array}$ & $\begin{array}{l}\text { Signi- } \\
\text { ficance }\end{array}$ \\
\hline $\begin{array}{l}\text { One hour } \\
\text { Mean } \\
\text { Standard deviation }\end{array}$ & $\begin{array}{l}5 \cdot 3 \\
2 \cdot 1\end{array}$ & $\begin{array}{l}6 \cdot 9 \\
2 \cdot 4\end{array}$ & $\begin{array}{l}p<0.05 \\
p>0.02\end{array}$ \\
\hline $\begin{array}{l}\text { Two hours } \\
\text { Mean } \\
\text { Standard deviation }\end{array}$ & $\begin{array}{l}6 \cdot 7 \\
2 \cdot 5\end{array}$ & $\begin{array}{l}7 \cdot 9 \\
2 \cdot 5\end{array}$ & $p>0 \cdot 10$ \\
\hline
\end{tabular}

There was no significant difference in the levels of serum tryptophane either before the test or at one or two hours after loading (Table 2). However, when the actual rise in serum tryptophane over and above the fasting levels was calculated (Table 3), it could be shown that this was less in the children with mongolism and that the difference between them and the controls was probably significant $(p=<0.05$ and $>0.02)$ at one hour.

\section{Discussion}

Orally administered 1-tryptophane is partly metabolized by the flora of the bowel to indole derivatives. These are absorbed and excreted in the urine principally as indican, indoleacetic and indolelactic acids (Fig. 2), the last two compounds being also the products of endogenous metabolism. Of the 1-tryptophane entering the blood stream, a certain proportion will be incorporated into tissue proteins. In adults in nitrogen balance, about $1 \%$ of the residue (Udenfriend, Weissbach and Sjoerdsma, 1956) is metabolized via serotonin to 5-hydroxyindoleacetic acid, a further small amount is excreted directly as tryptophane and the greater part of the remainder is broken down to 3-hydroxyanthranilic acid and then via glutarate and acetate to $\mathrm{CO}_{2}$ (Gholson, Sanders and Henderson, 1959). Finally, some 3-hydroxyanthranilic acid is converted 


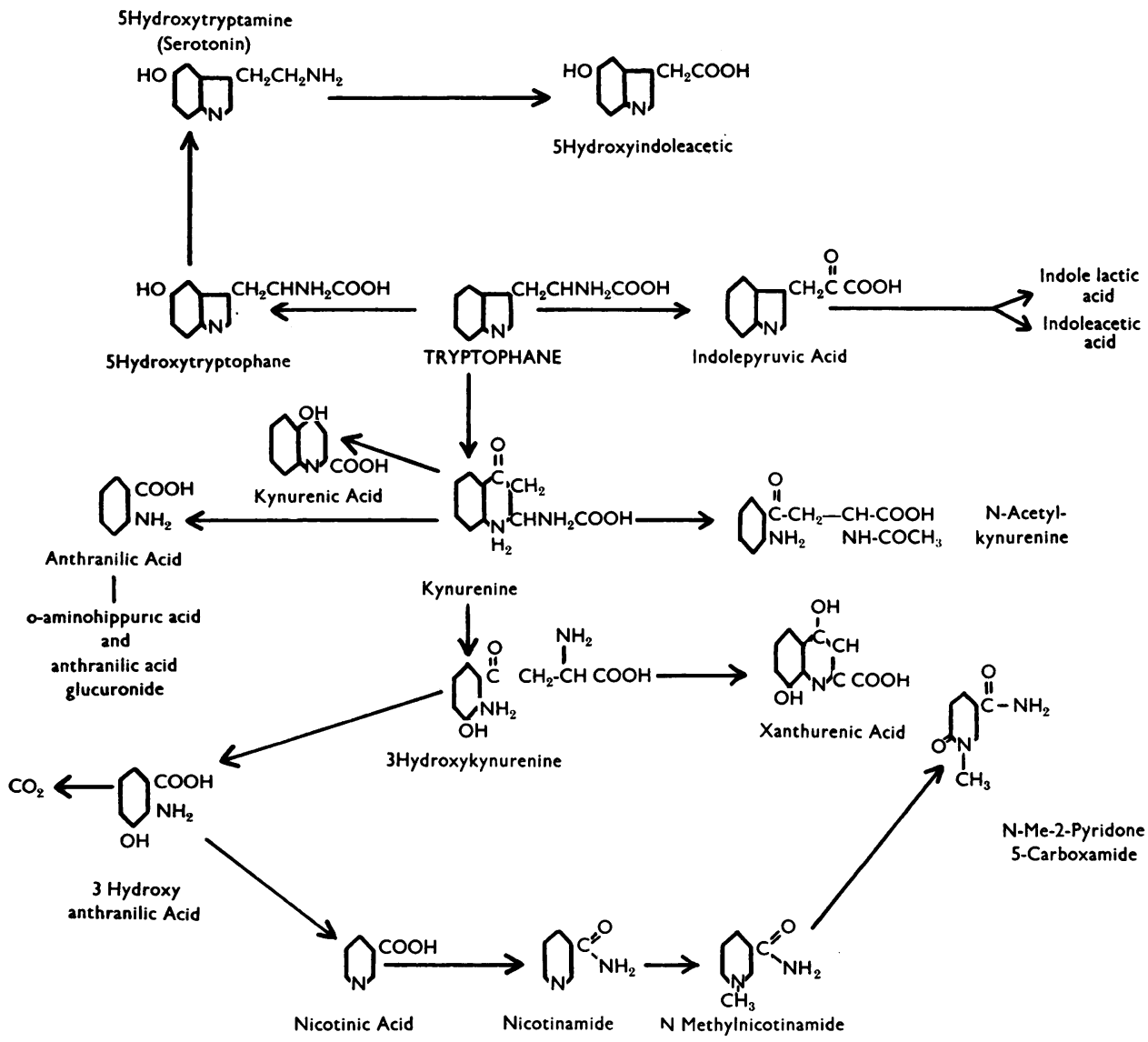

Fig. 2.-Metabolism of tryptophane.

to nicotinic acid appearing in the urine as $\mathrm{N}^{1}$ methylnicotinamide and N-methyl-2-pyridone-5carboxamide.

In this study the results confirm previous observations (Gershoff et al., 1958; Jérôme et al., 1960; O'Brien et al., 1960) that, in children with mongolism, there is a decreased urinary excretion of xanthurenic acid following an oral dose of tryptophane. Clearly there are a number of possible causes for this finding. One explanation suggested by the serum tryptophane levels at one hour is that of tryptophane malabsorption. However, this appears improbable for two reasons. In the first place, it would be expected to lead to an increased urinary excretion of indole derivatives as is the case in Hartnup disease (Shaw, Redlich, Wright and Jepson, 1960) and other malabsorption states (Haverback, Dyce and Thomas, 1960) instead of to the observed decrease in urinary indoleacetic acid
(Jérôme et al., 1960). Secondly, significant reductions in the urinary excretion coefficients (Fig. 1) in this series are not uniform but appear to be unique for xanthurenic acid and to a less significant extent for acetyl kynurenine, a point that is also against an increased renal clearance of unmetabolized tryptophane.

If the data are examined another way and the product : substrate ratios in the urine are calculated for acetyl kynurenine to kynurenine and xanthurenic acid to hydroxykynurenine, it is apparent that the low urinary excretion of acetyl kynurenine in children with mongolism is not significant considering their lower kynurenine excretion. However, in the case of xanthurenic acid, the decreased urinary excretion in the children with mongolism does not appear to be similarly explicable in terms of a diminished availability of hydroxykynurenine. Thus it appears that in the children with mongolism 
TABLE 4

PRODUCT: SUBSTRATE RATIOS IN THE KYNURENINE PATHWAY

\begin{tabular}{|c|c|c|c|}
\hline & Mongols & $\begin{array}{c}\text { Non- } \\
\text { mongols }\end{array}$ & $\begin{array}{l}\text { Signi- } \\
\text { ficance }\end{array}$ \\
\hline $\begin{array}{l}\text { Acetylkynurenine: } \\
\text { kynurenine } \\
\text { Mean } \\
\text { Standard deviation .. } \\
\text { Number of observa- } \\
\text { tions }\end{array}$ & $\begin{array}{l}0 \cdot 56 \\
0 \cdot 38 \\
\\
20\end{array}$ & $\begin{array}{l}0.71 \\
0.16 \\
19\end{array}$ & $\mathrm{p}>0 \cdot 10$ \\
\hline $\begin{array}{l}\text { Xanthurenic acid: } \\
\text { hydroxykynurenine } \\
\text { Mean } \\
\text { Standard deviation .. } \\
\text { Number of observa- } \\
\text { tions }\end{array}$ & $\begin{array}{l}0.40 \\
0.35 \\
18\end{array}$ & $\begin{array}{l}0 \cdot 85 \\
0 \cdot 70 \\
\\
15\end{array}$ & $\begin{array}{l}p<0.05 \\
p>0.02\end{array}$ \\
\hline $\begin{array}{c}\text { Hydroxyanthranilic acid: } \\
\text { hydroxykynurenine } \\
\text { Mean } \\
\text { Standard deviation .. } \\
\text { Number of observa- } \\
\text { tions } \quad .\end{array}$ & $\begin{array}{l}0.93 \\
0.34 \\
18\end{array}$ & $\begin{array}{l}0.68 \\
0.43 \\
14\end{array}$ & $p>0.10$ \\
\hline
\end{tabular}

there may be a specific abnormality of hydroxykynurenine transaminase resulting in a diminished conversion of hydroxykynurenine to xanthurenic acid. For final proof, however, it would be necessary both to measure urinary xanthurenic acid after the intravenous administration of its precursor hydroxykynurenine, and to demonstrate a normal renal clearance of xanthurenic acid per unit of glomerular filtrate.

Vitamin $\mathbf{B}_{6}$ deficiency appeared to play no part in these changes in tryptophane metabolism not only because there was no difference between the groups in 4-pyridoxic acid excretion but, more importantly, because the most sensitive index of pyridoxine deficiency and dependency, the ratio of urinary hydroxyanthranilic acid to hydroxykynurenine (Table 4), was not decreased. It remains a possibility, however, that the apoenzyme of hydroxykynurenine transaminase in children with mongolism has an altered affinity for pyridoxal phosphate.

Finally, this study did not confirm previous observations suggesting a defect in the methylation of nicotinamide in children with mongolism (Gershoff et al., 1958). Nevertheless, there is a possibility that these children have other less defined impairments of tryptophane metabolism from the significantly lowered values for urinary hydroxyindoleacetic acid (Jérôme et al., 1960; Gershoff, personal communication) and indoleacetic acid
(Jérôme et al., 1960) found in certain instances after tryptophane loading.

\section{Summary}

The seven-hour urinary excretion coefficients of 5HIAA, kynurenic acid, xanthurenic acid, kynurenine, hydroxykynurenine, hydroxyanthranilic acid, methylnicotinamide and 4-pyridoxic acid were measured in 21 children with mongolism and in a comparable group of 19 non-mongoloid mental defectives after an oral load of $100 \mathrm{mg} . / \mathrm{kg}$. of 1-tryptophane.

The results suggest an abnormality of hydroxykynurenine transaminase resulting in diminished conversion of hydroxykynurenine to xanthurenic acid in the children with mongolism.

This study was supported by the John and Mary Markle Foundation and by U.S.P.H.S. grant M2347.

\section{REFERENCES}

Asami, T. (1957). A simple method for the determination of $N^{1}$. methylnicotinamide in urine. J. Vitaminol., 3, 189.

Coppini, D., Benassi, C. A. and Montorsi, M. (1959). Quantitative determination of tryptophan metabolites (via kynurenine) in biologic fluids. Clin. Chem., 5, 391.

Gershoff, S. N., Hegsted, D. M. and Trulson, M. F. (1958). Metabolic studies of mongoloids. Amer. J. clin. Nutr., 6, 526.

Gholson, R. K. Sanders, D. C. and Henderson, L. M. (1959). Glutaric acid: A product of tryptophan metabolism. Biochem. biophys. Res. Comm. 1, 98

Haverback, B. J., Dyce, B. and Thomas, H. V. (1960). Indole metabolism in the malabsorption syndrome. New Engl. J. Med., 262, 754 .

Huff, J. W. and Perlzweig, W. A. (1947). The fluorescent condensation product of $\mathrm{N}^{1}$-methylnicotinamide and acetone. J. biol. Chem., 167, 157.

Jérôme, H., Lejeune, J. and Turpin, R. (1960). Étude de l'excrétion urinaire de certains métabolites du tryptophane chez les enfants mongoliens. C.R. Acad. Sci. Paris, 251, 474.

O'Brien, D., Groshek, A. P. and Streamer, C. W. (1960). Abnormalities of tryptophan metabolism in children with mongolism. A.M.A. J. Dis. Child., 100, 540

- and Ibbott, F. (1962a). Laboratory Manual of Pediatric Microand Ultramicro-biochemical Techniques, 3rd ed., p 304. Hoeber, New York.

Re (1962b). ibid., p. 242.

Reddy, S. K., Reynolds, M. S. and Price, J. M. (1958). The determination of 4-pyridoxic acid in human urine. J. biol. Chem. 233, 691 .

Satoh, K. and Price, J. M. (1958). Fluorometric determination of kynurenic acid and xanthurenic acid in human urine. ibid., 230, 781

Shaw, K. N. F., Redlich, D., Wright, S. W. and Jepson, J. B. (1960). Dependence of urinary indole excretion in Hartnup disease upon gut flora. Fed. Proc., 19, 194.

Trickett, W. H., Welch, B. L. and James, G. S. (1956). Further critical values for the two-means problem. Biometrika, 43, 203.

Udenfriend, S., Titus, E. and Weissbach, H. (1955). The identification of 5-hydroxy-3-indoleacetic acid in normal urine and a fication of 5-hydroxy-3-indoleacetic acid in normal , Weissbach, H. and Sjoerdsma, A. (1956). Studies on tryptophan and serotonin in patients with malignant carcinoid. Science, 123, 669. 